\title{
The Anomalous Stock Market Behavior of Big and Low Book-to-Market Equity Firms in April: New Evidence from Japan
}

\author{
Chikashi Tsuji*
}

\author{
Graduate School of Systems and Information Engineering, University of Tsukuba, Japan
}

\begin{abstract}
This paper shows that in Japan, big and low book-to-market equity firms experience higher risk-adjusted returns in April. We also reveal that volatility in April is significantly lower than in other months. Furthermore, we demonstrate that several trading strategies using this April effect can produce profitable returns, even after considering transaction costs. Moreover, additional analysis using the trading volume of financial institutions implies that the abnormally higher returns of big firms and low book-to-market equity firms appear to be derived not from the tax-loss selling effect but mainly from the dressing-up behavior of Japanese financial institutions at the end of the fiscal year.
\end{abstract}

Keywords: January effect, April effect, information and market efficiency, turn-of-the-year effect, sharpe ratio, tax-loss selling effect.

\section{INTRODUCTION}

Is there an anomaly in Japan similar to the well-known January effect in the US? The January effect was first documented by Rozeff and Kinney [1], Keim [2] and Reinganum [3]. ${ }^{1}$ Keim [2] found that about half of the annual size effect in the US can be attributed to January and that much of the January effect occurs during the first few trading days of the month. This January effect is considered to be one of the most prominent anomalies in finance. ${ }^{2}$ Reinganum [3] also confirmed that the US January effect holds during the first few trading days of the month in smaller-size portfolios. However, in Japan, the study of seasonal anomalies is quite limited. As far as we are aware, only two academic studies concern seasonal anomalies in Japan. First, Kato and Schallheim [31] found that the January effect also exists in Japan. Second, Gultekin and Gultekin [32] investigated 17 countries, including Japan, and also found evidence of an international January effect.

In comparison with the preceding US work and the two existing studies for Japan, our study differs in the following respects. First, we investigate larger-size portfolios, not smaller-size portfolios. Second, we analyze the lowest bookequity-to-market-equity (BE/ME) portfolios. It is typical for

*Address correspondence to this author at the Graduate School of Systems and Information Engineering, University of Tsukuba, 1-1-1 Tennodai, Tsukuba, Ibaraki 305-8573 Japan; E-mail: mail_sec_low@minos.ocn.ne.jp

\footnotetext{
${ }^{1}$ Many studies concern the January effect in the US. These include Branch [4], Roll [5, 6], Blume and Stambaugh [7], Brauer and Chang [8], Sias and Starks [9], Grundy and Martin [10], Poterba and Weisbenner [11], Ali et al. [12], Vorkink [13], Grinblatt and Keloharju [14], Grinblatt and Moskowitz [15], Ng and Wang [16], Starks et al. [17], and Cooper et al. [18].

${ }^{2}$ Other anomalies documented in the US are the small-firm effect (Banz [19], Reinganum [20, 21], Roll [22], James and Edmister [23], Brown et al. [24], and Stoll and Whaley [25]), the value effect (Fama and French [26]), momentum returns (Jegadeesh and Titman [27], Rouwenhorst [28]), and return reversals (Jegadeesh and Titman [29], DeBondt and Thaler [30]).
}

existing research on the January effect to consider firm size and the January effect, as in Keim [2], Reinganum [3], or Kato and Schallheim [31], among others. Hence, we have a different research perspective by considering the lowest$\mathrm{BE} / \mathrm{ME}$ portfolio. Third, we do not consider the January effect rather the April effect while paying attention to the riskreturn trade-off. Thus, our paper is the first to document evidence of higher risk-adjusted returns in April for larger and lower-BE/ME firms in Japan. We refer to this phenomenon as the 'April effect'.

Our main contributions are as follows. First, we provide new evidence that the biggest (largest firm size) portfolio of 25 size-ranked portfolios in Japan earns the highest riskadjusted returns in April. Second, we also find that the lowest-BE/ME-ranked portfolio of $25 \mathrm{BE} / \mathrm{ME}-$ ranked portfolios exhibits relatively higher risk-adjusted returns in April. Third, we confirm that in these portfolios, volatility is lowest in April, and we confirm our findings from the viewpoint of the time-varying volatilities. Fourth, we suggest that this April effect in Japan is not because of the more well-known tax-loss selling hypothesis (as suggested by Reinganum [3], Branch [4], Poterba and Weisbenner [11], among others) but because of the dressing-up behavior of financial institutions at the end of the Japanese fiscal year. Finally, we also reveal that almost all trading strategies constructed using the April effect successfully beat the market.

The rest of this paper is organized as follows. Section II explains the data used. Section III includes the test methodology and the results. Section IV interprets the results, and Section V considers the profitability of trading strategies using the April effect. Section VI concludes the paper.

\section{DATA}

Our full sample period is from January 1982 to December 2007. First, we construct 25 size-ranked portfolios and $\mathrm{BE} / \mathrm{ME}-$ ranked portfolios for the Japanese market. ${ }^{3}$ We use

\footnotetext{
${ }^{3}$ We follow Fama and French [33] in constructing the two sets of 25 portfolios.
}

2009 Bentham Open 
return data for the Tokyo Stock Exchange (TSE) First Section from the Japan Securities Research Institute (JSRI). We then compute the value-weighted returns of the biggest portfolio and the lowest-BE/ME portfolio, and use them in our analysis.

For the statistical tests in the next section, we compute the Sharpe ratio as $\left[R_{p, t}-R_{f, t}\right] / \sigma$, where $R_{p, t}$ is the annualized return of the biggest portfolio or the lowest-BE/ME portfolio, $R_{f, t}$ is the annual risk-free rate, and $\sigma$ is the annualized volatility of portfolio returns. For the risk-free rate, we employ the yields of traded bonds with repurchase agreements (from the Japan Securities Dealers Association) ${ }^{4}$ from January 1982 to May 1984, and the one-month median rate of negotiable time certificates of deposit (CD) from the Bank of Japan for June 1984 to December 2007. ${ }^{5}$ We employ the annualized standard deviation of the portfolio's returns during the whole sample period as the measure of volatility, $\sigma$.

\section{THE APRIL EFFECT}

This section statistically tests for the April effect in the biggest and lowest-BE/ME portfolios in Japan. For the statistical tests, we use the Sharpe ratio (1):

$$
S R_{t}=\frac{R_{p, t}-R_{f, t}}{\sigma} .
$$

Table 1 provides the annualized monthly Sharpe ratios for the biggest of 25 portfolios. At the bottom of Table $\mathbf{1}$, the average values of the Sharpe ratio of the biggest portfolio are displayed, where April has the highest value of 1.843. Consequently, on average, the biggest portfolio in Japan earns the highest risk-adjusted returns in April.

Table 2 displays the annualized monthly Sharpe ratio for the lowest-BE/ME portfolio of 25 portfolios. At the bottom of Table 2, the average Sharpe ratios of the lowest-BE/ME portfolio are provided, and with the exception of 0.999 in January, the value of 0.953 in April is the highest. Hence, on average, the lowest-BE/ME portfolio earns the highest riskadjusted returns in January and April.

Next, we describe the procedure and results of the statistical tests for the April effect. We use the following $t$-statistic $T$ for the tests:

$$
T=\frac{A V G\left[S R_{\text {April }}\right]-A V G\left[S R_{\text {others }}\right]}{\sigma / \sqrt{n}},
$$

where $A V G\left[S R_{A p r i l}\right]$ is the average value of the April Sharpe ratios, $A V G\left[S R_{\text {other }}\right]$ is the average value of the Sharpe ratios in other months, $\sigma$ is the standard deviation of April's Sharpe ratios, and $n$ is the number of sample observations. The null hypothesis is $\mathrm{H}_{0}: A V G\left[S R_{\text {April }}\right]=A V G\left[S R_{\text {others }}\right]$; and the alternative is $\mathrm{H}_{1}: A V G\left[S R_{A p r i l}\right]>A V G\left[S R_{\text {others }}\right]$. Under the null hypothesis, the $t$-statistic $T$ has a $t$-distribution with degrees of freedom of $n-1$. If April's Sharpe ratio of the tested portfolio is statistically significantly higher than the Sharpe ratios in the other months using the above $t$-test, we reject the null.

\footnotetext{
${ }^{4}$ Hamao [34] used the risk-free rate because there is no indicator in Japan corresponding to the US 30-day Treasury bill rate.

${ }^{5}$ In Japan, the one-month CD rate is unavailable until June 1984.
}

Table $\mathbf{3}$ shows the results of the test for the April effect in the biggest and lowest-BE/ME portfolios in Japan. As shown in Panel A, the null hypothesis is rejected at least at the 5 percent level compared with the other months except March and December. Thus, the April effect in Japan is statistically significant in the biggest portfolio. As shown in Panel B, the null hypothesis is rejected at least at the 10 percent level except for January, ${ }^{6}$ March, October, and November. Hence, the April effect is statistically significant in the lowestBE/ME portfolio supported except for January, March, October, and November.

Using equation (2), we also test the January effect in the lowest-BE/ME portfolio and display the results in Table 4. As shown, the January effect in Table $\mathbf{4}$ has the level of statistical significance as the April effect in Table 3. We also note that in Table 4, we fail to reject the null hypothesis that the January Sharpe ratio equals the April Sharpe ratio. Therefore, we suggest that in the lowest-BE/ME portfolio, both the January effect and the April effect have the same level of statistical significance.

As above, our evidence of the Japanese April effect in the biggest-size and lowest-BE/ME firms is quite novel and differs from existing evidence in the US. This is because the January effect in the US is usually found only in small firms. We also investigated smaller-size and higher-BE/ME portfolios in Japan. However, we found no evidence of the April effect in these portfolios.

\section{INTERPRETATION}

What is the situation underlying the April effect in Japan? More specifically, how can we interpret the April effect in the biggest and lowest-BE/ME portfolios? This section interprets the observed April effect from two perspectives; namely, the risk-return trade-off and the tax-loss selling hypothesis.

\section{Risk-Return Trade-Off}

First, we discuss the April effect in Japan from the viewpoint of the risk-return trade-off. As shown in Fig. (1), the biggest portfolio in Japan has the highest returns in March, April, and December. However, the volatilities of the portfolios in these months are quite different. More specifically, the volatilities are quite high in March and December and quite low in April. In particular, April has the lowest volatility of all months. By focusing on these three months, we cannot recognize a risk-return trade-off. Therefore, the April effect observed in the returns of the biggest portfolio in Japan is a rather anomalous phenomenon from the viewpoint of the risk-return trade-off in standard finance theory.

Similarly, by checking the risk-return relation in the lowest-BE/ME portfolio in Japan, we can see a similar pattern, as shown in Fig. (2). Fig. (2) shows that the lowestBE/ME portfolio in Japan has the highest returns in January, March, April, October, and November. However, the volatilities of the portfolios in these months are again very different. Roughly speaking, the volatilities in January and April are relatively low, while those in March, October, and November are relatively high. Once again, the volatility in April

\footnotetext{
${ }^{6}$ We do not display the $t$-values and $p$-values for the test of the April effect against the January effect because the January Sharpe ratio is only slightly larger than the April Sharpe ratio.
} 
Table 1. Annualized Monthly Sharpe Ratio for the Biggest of 25 Portfolios Formed on the Basis of Size: The Case of Japan from January 1982 to December 2007

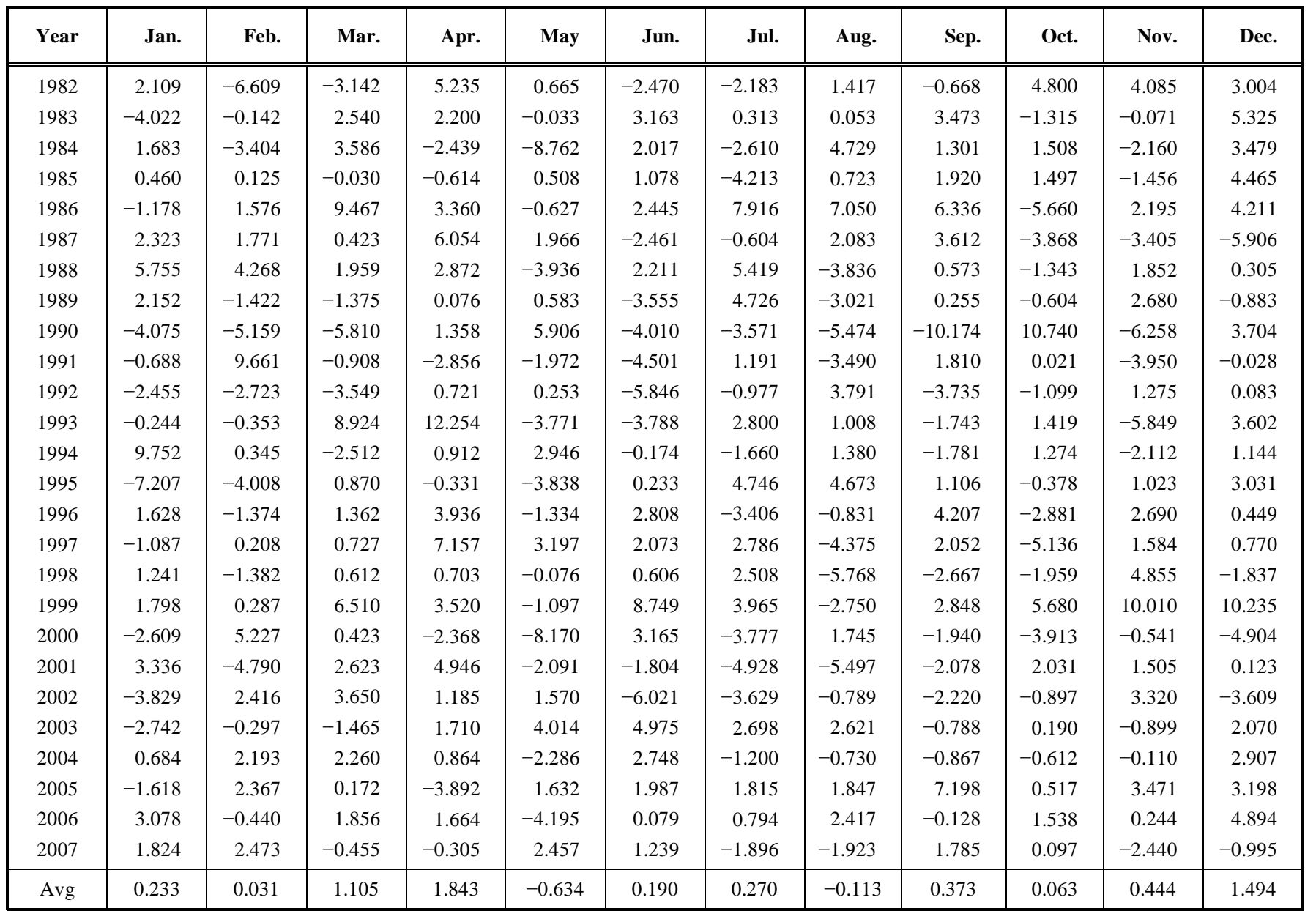

Notes: Monthly Sharpe ratios of the biggest of 25 size-ranked portfolios are displayed for the sample period from January 1982 to December 2007 . The 25 size-ranked portfolios are formed following the procedure in Fama and French [33]. That is, at the end of September each year $t$ (1981-2007), TSE (Tokyo Stock Exchange) First Section stocks are allocated to one of 25 groups based on their September market equity (ME, stock price times shares outstanding). The value-weighted monthly returns on the portfolios are then calculated from October to September of the following year. Only firms with ordinary common equity are included. REITs (Real Estate Investment Trusts) and units of beneficial interest are excluded. The Sharpe ratios are annualized. 'Avg' denotes the average.

is lowest for all months. Therefore, the April effect found in the lowest-BE/ME portfolio in Japan is again a rather anomalous phenomenon from the viewpoint of the riskreturn trade-off in standard finance theory.

We also perform $t$-tests using similar statistics to equation (2), for the volatility in April of both portfolios. The null hypothesis of the test is that the average volatility in April is the same as the other months. The alternative hypothesis is that the average volatility in April is lower than in other months. The results are shown in Table 5. Using Panel A, we can see that on average, the April volatility of the biggest portfolio in Japan is statistically significantly lower than other months at the $1 \%$ level with the exception of October. Similarly, Panel B shows that on average, the April volatility of the lowest-BE/ME portfolio in Japan is statistically significantly lower than other months with the exception of June and October.

To consider further the situation of risk, in Figs. (3) and (4), we depict the fitted volatilities of a time-varying EGARCH (exponential generalized autoregressive conditional heteroscedasticity) model of the biggest and the lowest-BE/ME portfolios. Fig. (3) displays the volatility in
March, April, and December of the biggest portfolio. Fig. (4) provides the volatilities of the lowest-BE/ME portfolio in January, March, April, October and November. All months in Figs. (3) and (4) have the highest returns in our fullsample period, as shown in Figs. (1) and (2). Based on these graphs, we can again appreciate that the biggest and lowest$\mathrm{BE} / \mathrm{ME}$ portfolios have the lowest risk in April from the perspective of time-varying risk. Accordingly, we can see that in both the biggest and lowest-BE/ME portfolios, the lower volatility and higher excess returns underlie the higher Sharpe ratios in April.

\section{Is the April Effect in Japan Derived from Tax-Loss Selling?}

We now move on to the second perspective, the tax-loss selling effect. If the higher Sharpe ratios of the biggest-size and lowest-BE/ME portfolios in Japan are indeed evidence of a tax-loss selling effect as suggested in the US, then returns should decline in March (the end of the Japanese fiscal year) and increase in April. What is the actual situation?

The respective risk and return in each month for the biggest and lowest-BE/ME portfolios in Figs. (1) and (2), 
Table 2. Annualized Monthly Sharpe Ratio for the Lowest-BE/ME Portfolio of 25 Portfolios Formed on the Basis of BE/ME: The Case of Japan from January 1982 to December 2007

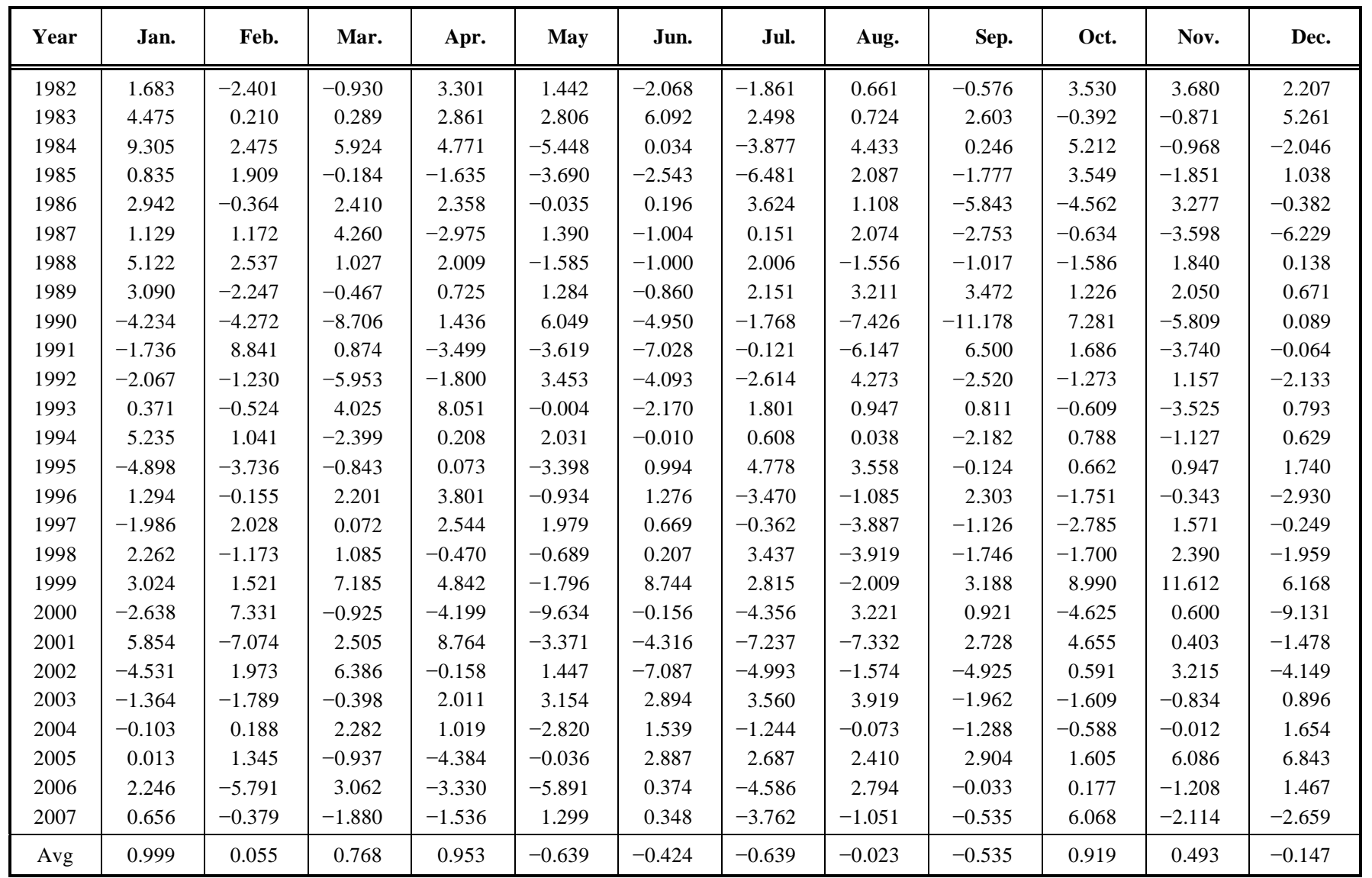

Notes: Monthly Sharpe ratios of the lowest-BE/ME portfolio of 25 BE/ME-ranked portfolios are for the sample period from January 1982 to December 2007. The 25 BE/ME-ranked portfolios are formed following the procedure in Fama and French [33]. That is, the BE/ME ratios used to form portfolios in September of year $t$ are the book common equity for fiscal year $t-1$ divided by the market equity at the end of March in calendar year $t$. We do not use negative BE firms when forming the BE/ME portfolios. Value-weighted monthly returns on the portfolios are then calculated from October to the following September. Only firms with ordinary common equity are included. REITs (Real Estate Investment Trusts) and units of beneficial interest are excluded. The Sharpe ratios are annualized. 'Avg' denotes the average.

Table 3. Test for the April Effect in the Biggest and Lowest-BE/ME Portfolio: The Case of Japan from January 1982 to December 2007

\begin{tabular}{|c|c|c|c|c|c|c|c|c|c|c|c|c|}
\hline \multicolumn{10}{|c|}{ Panel A Biggest Size Portfolio } \\
\hline Statistic & Jan. & Feb. & Mar. & May & Jun. & Jul. & Aug. & Sep. & Oct. & Nov. & Dec. \\
\hline \hline $\begin{array}{c}t \text {-statistic } \\
p \text {-value }\end{array}$ & $2.366^{* *}$ & $\begin{array}{l}2.664^{* *} \\
0.007\end{array}$ & $\begin{array}{l}1.086 \\
0.144\end{array}$ & $\begin{array}{l}3.642^{* *} \\
0.001\end{array}$ & $\begin{array}{l}2.430^{* *} \\
0.011\end{array}$ & $\begin{array}{l}2.312^{* *} \\
0.015\end{array}$ & $\begin{array}{l}2.876^{* *} \\
0.004\end{array}$ & $\begin{array}{l}2.162^{* *} \\
0.020\end{array}$ & $\begin{array}{l}2.617^{* *} \\
0.007\end{array}$ & $\begin{array}{l}2.057^{* *} \\
0.025\end{array}$ & $\begin{array}{l}0.514 \\
0.306\end{array}$ \\
\hline \multicolumn{10}{|c|}{ Panel B Lowest-BE/ME Portfolio } \\
\hline Statistic & Jan. & Feb. & Mar. & May & Jun. & Jul. & Aug. & Sep. & Oct. & Nov. & Dec. \\
\hline \hline$t$-statistic \\
$p$-value & - & $1.324^{*}$ & 0.273 & $2.348^{* *}$ & $2.031^{* *}$ & $2.348^{* *}$ & $1.440^{*}$ & $\begin{array}{l}2.194^{* *} \\
0.019\end{array}$ & $\begin{array}{l}0.050 \\
0.480\end{array}$ & $\begin{array}{l}0.678 \\
0.252\end{array}$ & $\begin{array}{l}1.622^{*} \\
0.059\end{array}$ \\
\hline
\end{tabular}

Notes : This table provides the $t$-statistics and $p$-values for the April effect in Japan. The null hypothesis is that the average Sharpe ratio in April is equal to the average in the other months. The alternative hypothesis is that the average Sharpe ratio in April is larger than the average in the other months. The sample period is from January 1982 to December 2007. $* *$ and $*$ denote that the values are statistically significant at the $5 \%$ and $10 \%$ level, respectively.

clearly indicate that the higher returns in March continue until April. This pattern of higher successive returns in March and April in both portfolios is also statistically significant. This is because in the test of the April effect conducted in Table 3, we were unable to reject the null hypothesis of no difference between the Sharpe ratios in March and April. On the basis of this evidence, we suggest that the
April effect in Japan is not derived from the tax-loss selling effect. $^{7}$

\footnotetext{
${ }^{7}$ Reinganum [3] concluded that in the US, “... while potential tax-loss selling may explain the extraordinary returns witnessed at the beginning of January, potential tax-loss selling does not seem capable of explaining the entire anomalous return behavior of small firms in January." (p. 102) Ac-
} 
Table 4. Test for the January Effect in the Lowest-BE/ME Portfolio: The Case in Japan from January 1982 to December 2007

\begin{tabular}{|c|c|c|c|c|c|c|c|c|c|c|c|}
\hline \multicolumn{12}{|c|}{ Lowest-BE/ME Portfolio } \\
\hline Statistic & Feb. & Mar. & Apr. & May & Jun. & Jul. & Aug. & Sep. & Oct. & Nov. & Dec. \\
\hline$t$-statistic & $1.400 *$ & 0.343 & 0.068 & $2.429 * *$ & $2.111^{* *}$ & $2.429 * *$ & $1.516^{*}$ & $2.275^{* *}$ & 0.118 & 0.750 & $1.699 *$ \\
\hline$p$-value & 0.087 & 0.367 & 0.473 & 0.011 & 0.022 & 0.011 & 0.071 & 0.016 & 0.453 & 0.230 & 0.051 \\
\hline
\end{tabular}

Notes : This table provides the $t$-statistics and $p$-values for the January effect in Japan. The null hypothesis is that the average Sharpe ratios in January is equal to the average in the other months. The alternative hypothesis is that the average Sharpe ratio in January is larger than the average in the other months. The sample period is from January 1982 to December 2007. ** and * denote that the values are statistically significant at the $5 \%$ and $10 \%$ level, respectively.

Table 5. Test for the level of Risk in April of the Biggest and the Lowest-BE/ME Portfolio: The Case in Japan from January 1982 to December 2007

\begin{tabular}{|c|c|c|c|c|c|c|c|c|c|c|c|}
\hline \multicolumn{12}{|c|}{ Panel A Biggest Size Portfolio } \\
\hline \multicolumn{12}{|c|}{ Panel B Lowest-BE/ME Portfolio } \\
\hline$t$-statistic & $2.015^{* *}$ & $1.794 * *$ & $3.026 * *$ & $1.576^{*}$ & 0.265 & $4.213 * *$ & $8.600^{* *}$ & $2.944 * *$ & 0.320 & $4.988^{* *}$ & $4.947 * *$ \\
\hline$p$-value & 0.027 & 0.042 & 0.003 & 0.064 & 0.396 & 0.000 & 0.000 & 0.003 & 0.376 & 0.000 & 0.000 \\
\hline
\end{tabular}

Notes : This table provides the $t$-statistics and $p$-values for volatility in April in Japan. The null hypothesis is that the average time-varying volatilities are equal to the average of the other months. The alternative hypothesis is that the average value of the time-varying volatilities in April is lower than the average value of other months. The sample period is from January 1982 to December 2007. ** and * denote that the values are statistically significant at the 5\% and $10 \%$ level, respectively.

How then can we interpret Japan's April effect? For an alternative, we provide Figs. $(\mathbf{5}, \mathbf{6})$. Fig. (5) exhibits the average trading volume (the sum of the buy and sell amounts) of financial institutions in the TSE First Section. The sample period of the trading volume is the maximum available period from January 1986 to December 2007. Fig. (6) provides the average share of the trading volume of financial institutions in total trading volume in the TSE First Section. The sample period is identical to Fig. (5).

As shown in Fig. (5), the yen trading volume of financial institutions in Japan is highest in March followed by April. Fig. (6) provides the average share of financial institutions in total trading volume. Yet again, April follows March. Using these findings, we can see that Japanese financial institutions trade more in March when the fiscal year ends. We suggest that this is then consistent with a turn-of-the-year effect (Roll [6]). ${ }^{8}$ More specifically, Japanese financial institutions generally trade bigger stocks more than smaller stocks and more-reputable stocks more than less-reputable stocks. More-reputable stocks generally have higher market values; thus, they also generally have a lower BE/ME. Therefore, we suggest that because of the turn-of-the-year effect, Japanese financial institutions trade more bigger-size and lower$\mathrm{BE} / \mathrm{ME}$ stocks in March and April.

However, what is the exact reason for Japanese financial institutions trading these stocks in March and April? We suggest that their aim is not to reduce their tax payments by selling value-decreasing stocks in March but rather to dress up

cordingly, tax-loss selling is not even regarded as a perfect justification for the US January effect.

${ }^{8}$ The turn-of-the-year effect is generally interpreted as evidence of a shift in the demand and supply for stocks around the turn of the year.

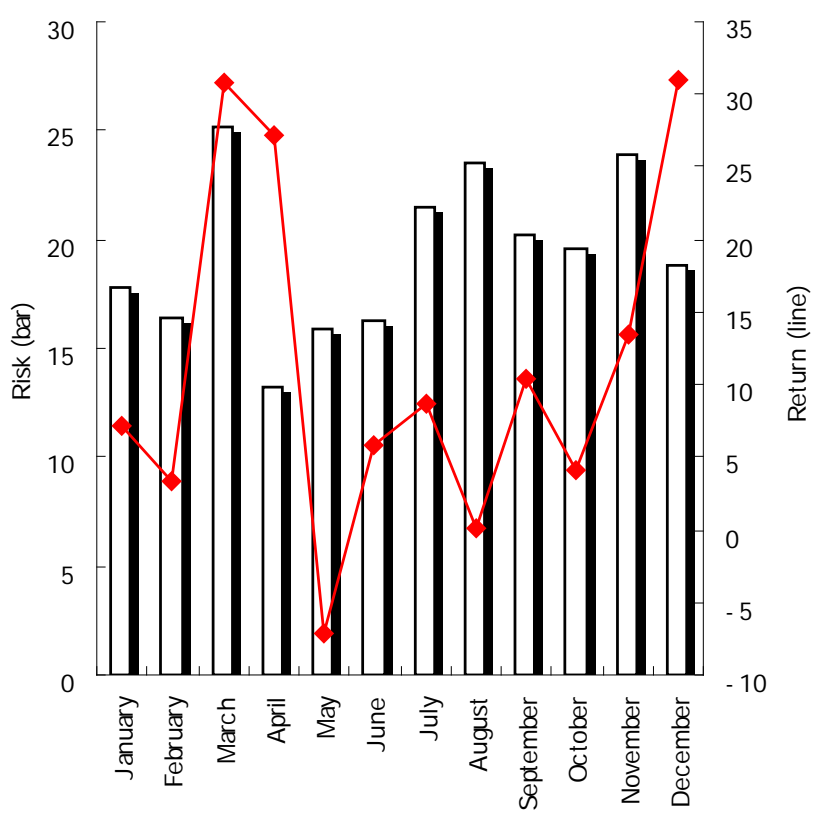

Fig. (1). Risk and return relation of the biggest-size portfolio in Japan.

their portfolios or assets by buying bigger and lower-BE/ME (higher market value) stocks. This is because in Japan, stock holdings as of the end of the fiscal year (i.e., March) are always reported to customers and other stakeholders. Moreover, if the large trading volume of financial institutions results from this dressing-up effect (in contrast to US tax-loss selling), trading does not necessarily end in March and may continue into April. We consider that this interpretation explains 
very well not only the higher returns of the biggest-size and lowest-BE/ME portfolios in March and April in Japan but also the higher trading volume of Japanese financial institutions in March and April. Therefore, as an original contribution, we interpret the April effect in Japan as a combination of a turnof-the-year effect and a dressing-up effect.

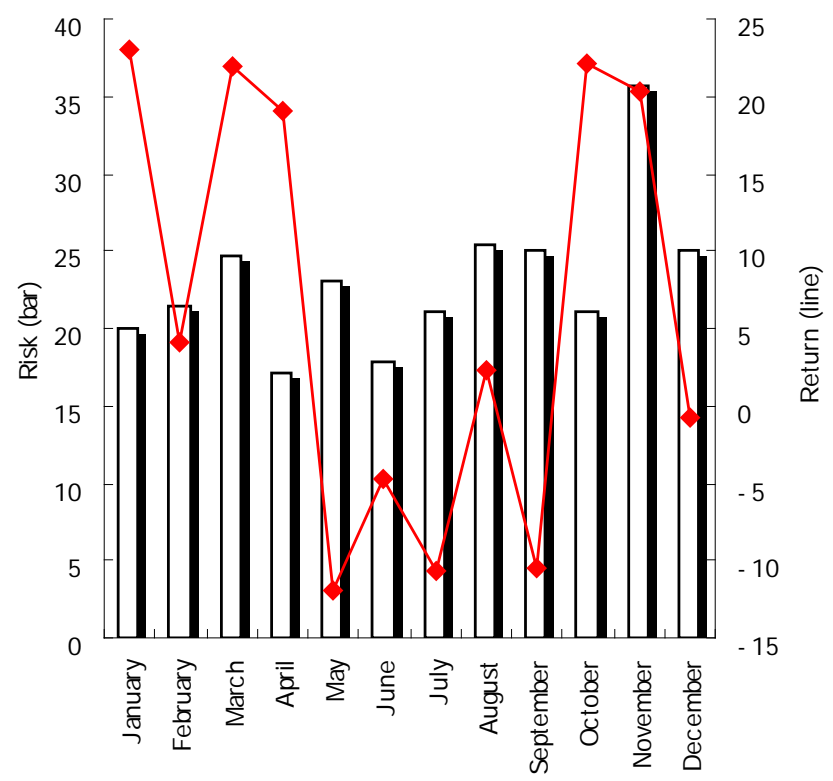

Fig. (2). Risk and return relation of the lowest-BE/ME portfolio in Japan.

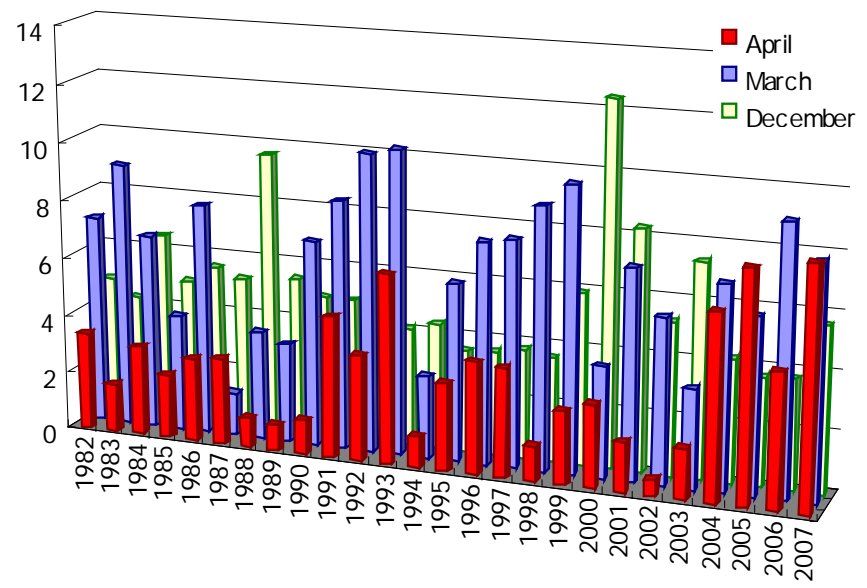

Fig. (3). EGARCH monthly volatility of the biggest-size portfolio.

\section{TRADING STRATEGIES USING THE APRIL EF- FECT}

Based on the evidence presented so far, this section clarifies whether trading strategies using the April effect are profitable.

\section{Biggest-Size Portfolio}

As shown in Fig. (1), the biggest-size portfolio in Japan earns higher returns in March, April, and December. Hence, we implement four strategies for the biggest portfolio, which

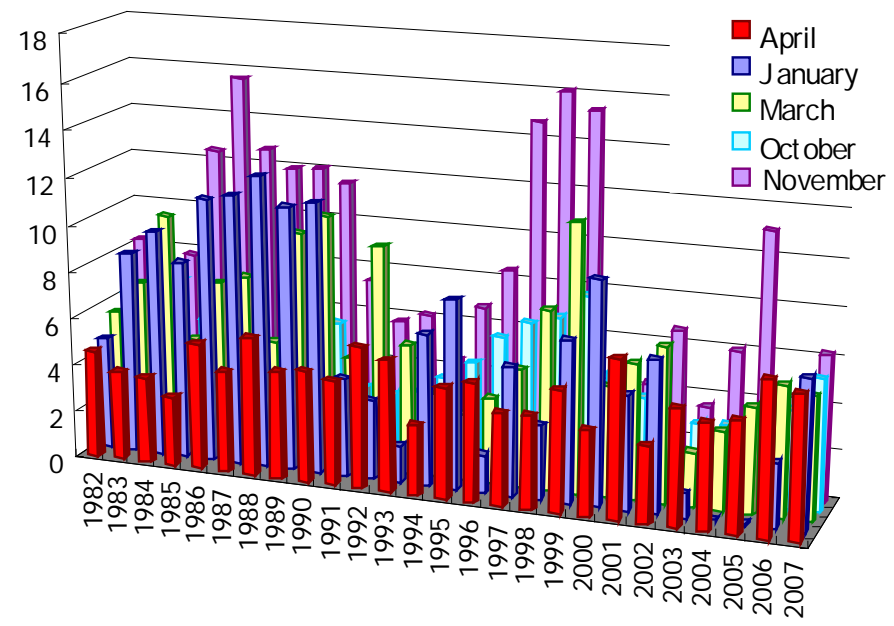

Fig. (4). EGARCH monthly volatility of the lowest-BE/ME portfolio.

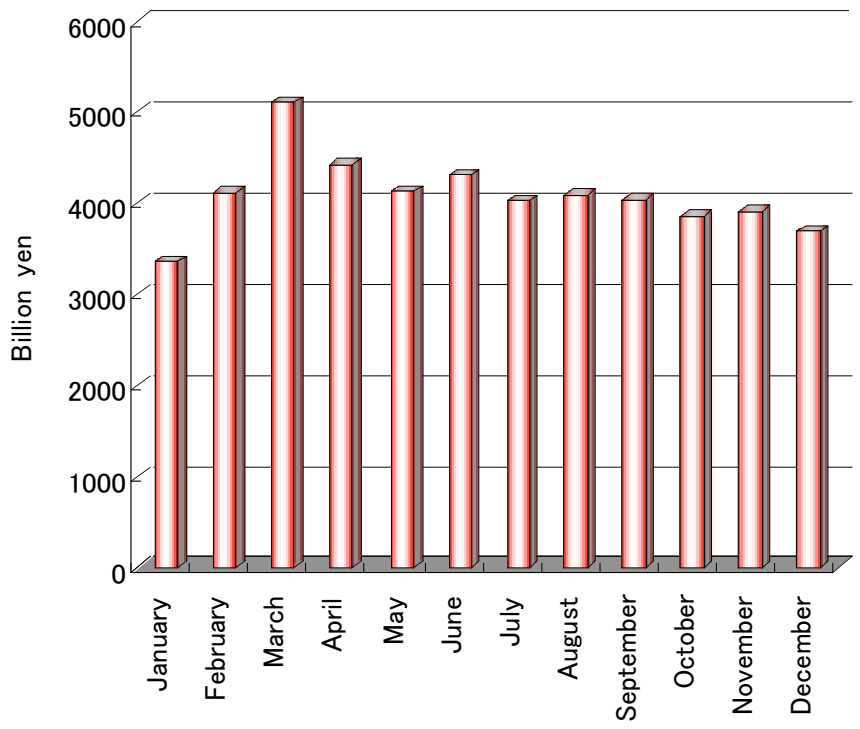

Fig. (5). Average trading volume of financial institutions in the Tokyo Stock Exchange, first section.

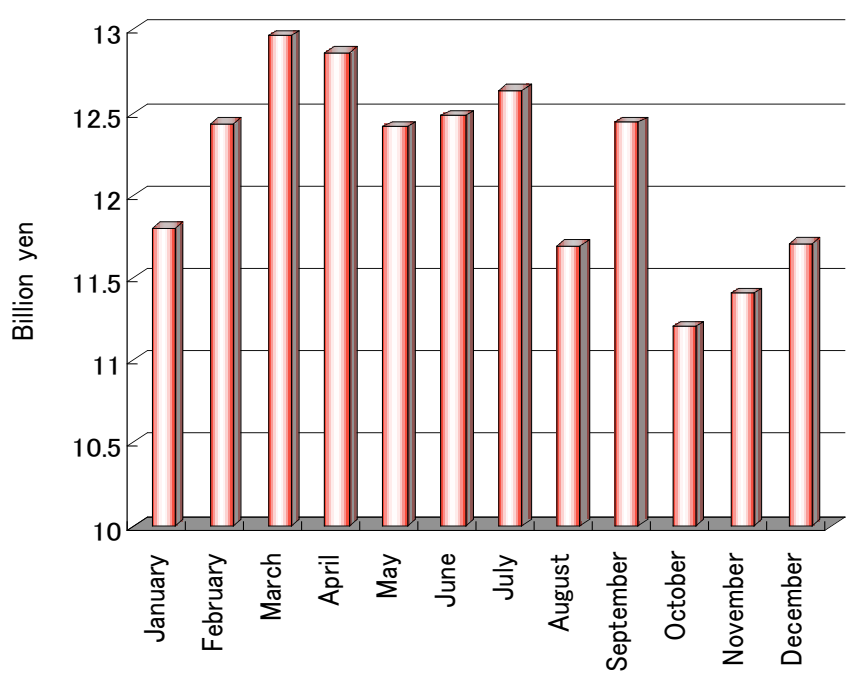

Fig. (6). Average share of trading volume of financial institutions in the Tokyo Stock Exchange, first section. 
we refer to as the 'April strategy', the 'March/April strategy', the 'April/December strategy', and the 'March/April/ December strategy'.

The 'April strategy' is a trading rule that we buy the biggest portfolio at the end of March and sell it at the end of April. Using this strategy, we can obtain the April return of the biggest portfolio. The 'March/April strategy' is a trading rule that we buy the biggest portfolio at the end of February and sell it at the end of April. Using this strategy, we can obtain the returns of the biggest portfolio in March and April. The 'April/December strategy' is a trading rule that we buy the biggest portfolio at the end of March and sell it at the end of April, and buy the portfolio again at the end of weighted average return of all stocks listed on the TSE First Section, as provided by the JSRI. We also show the results for three different sample periods: the full-sample period from January 1982 to December 2007, an earlier subsample period from January 1982 to December 1994, and a later subsample period from January 1995 to December 2007. All returns in Table $\mathbf{6}$ are after deducting transaction costs. In terms of the transaction costs, following Stoll and Whaley [35] and Billingsley and Chance [36], we use $0.85 \%$ for a round-trip transaction. ${ }^{9}$

Table $\mathbf{6}$ has the following features. First, the 'April strategy' produces positive profits not only in raw returns but also in excess returns. In particular, Panel B shows that the

Table 6. Profits for the Biggest Portfolio from Investment Strategies Using the April Effect: The Case of Japan from January 1982 to December 2007

\begin{tabular}{|c|c|c|c|c|c|c|c|c|c|}
\hline \multicolumn{10}{|c|}{ Panel A Raw Return } \\
\hline \multirow[b]{2}{*}{ Strategies } & \multicolumn{3}{|c|}{$\begin{array}{l}\text { Full-Sample Period: } \\
\text { January 1982-December } 2007\end{array}$} & \multicolumn{3}{|c|}{$\begin{array}{l}\text { Subsample Period: } \\
\text { January 1982-December } 1994\end{array}$} & \multicolumn{3}{|c|}{$\begin{array}{c}\text { Subsample Period: } \\
\text { January 1995-December } 2007\end{array}$} \\
\hline & $\begin{array}{l}\text { Transaction } \\
\text { Times }\end{array}$ & $\begin{array}{l}\text { Average } \\
\text { Yearly } \\
\text { Return }\end{array}$ & $\begin{array}{l}\text { Gross } \\
\text { Return }\end{array}$ & $\begin{array}{l}\text { Transaction } \\
\text { Times }\end{array}$ & $\begin{array}{l}\text { Average } \\
\text { Yearly } \\
\text { Return }\end{array}$ & $\begin{array}{l}\text { Gross } \\
\text { Return }\end{array}$ & $\begin{array}{l}\text { Transaction } \\
\text { Times }\end{array}$ & $\begin{array}{l}\text { Average } \\
\text { Yearly } \\
\text { Return }\end{array}$ & $\begin{array}{l}\text { Gross } \\
\text { Return }\end{array}$ \\
\hline April & 26 & 26.348 & 685.050 & 13 & 34.062 & 442.802 & 13 & 18.634 & 242.248 \\
\hline March/April & 26 & 28.147 & 731.829 & 13 & 28.637 & 372.277 & 13 & 27.658 & 359.552 \\
\hline April/December & 52 & 27.441 & 713.463 & 26 & 34.803 & 452.443 & 26 & 20.078 & 261.020 \\
\hline March/April/December & 52 & 27.993 & 727.812 & 26 & 30.656 & 398.530 & 26 & 25.329 & 329.282 \\
\hline \multicolumn{10}{|c|}{ Panel B Excess Return } \\
\hline & \multicolumn{3}{|c|}{$\begin{array}{l}\text { Full-Sample Period: } \\
\text { January 1982-December } 2007\end{array}$} & \multicolumn{3}{|c|}{$\begin{array}{c}\text { Subsample Period: } \\
\text { January 1982-December } 1994\end{array}$} & \multicolumn{3}{|c|}{$\begin{array}{c}\text { Subsample Period: } \\
\text { January 1995-December } 2007\end{array}$} \\
\hline Strategies & $\begin{array}{c}\text { Average } \\
\text { Yearly } \\
\text { Market } \\
\text { Return }\end{array}$ & $\begin{array}{c}\text { Average } \\
\text { Yearly } \\
\text { Excess } \\
\text { Return }\end{array}$ & $\begin{array}{l}\text { Gross } \\
\text { Excess } \\
\text { Return }\end{array}$ & $\begin{array}{c}\text { Average } \\
\text { Yearly } \\
\text { Market } \\
\text { Return }\end{array}$ & $\begin{array}{c}\text { Average } \\
\text { Yearly } \\
\text { Excess } \\
\text { Return }\end{array}$ & $\begin{array}{l}\text { Gross } \\
\text { Excess } \\
\text { Return }\end{array}$ & $\begin{array}{c}\text { Average } \\
\text { Yearly } \\
\text { Market } \\
\text { Return }\end{array}$ & $\begin{array}{c}\text { Average } \\
\text { Yearly } \\
\text { Excess } \\
\text { Return }\end{array}$ & $\begin{array}{l}\text { Gross } \\
\text { Excess } \\
\text { Return }\end{array}$ \\
\hline April & 9.577 & 16.771 & 436.050 & 13.369 & 20.692 & 269.002 & 5.785 & 12.850 & 167.048 \\
\hline March/April & 9.577 & 18.570 & 482.829 & 13.369 & 15.267 & 198.477 & 5.785 & 21.873 & 284.352 \\
\hline April/December & 9.577 & 17.864 & 464.463 & 13.369 & 21.434 & 278.643 & 5.785 & 14.294 & 185.820 \\
\hline March/April/December & 9.577 & 18.416 & 478.812 & 13.369 & 17.287 & 224.730 & 5.785 & 19.545 & 254.082 \\
\hline
\end{tabular}

Notes: 'Transaction times' is the number of transactions of each strategy in each sample period. 'Average yearly return' is the average annual percentage return from each strategy over each sample period. 'Gross return' is the gross percentage return from each strategy for each sample period. 'Average yearly market return' is the annual percentage return of the weighted average return of TSE First Section listed stocks in each sample period. 'Average yearly excess return' is the annual percentage excess return from each strategy over each sample period. 'Gross excess return' is the gross percentage excess return over the weighted average return of TSE First Section listed stocks from each strategy for each sample period.

November and sell it at the end of December. Using this strategy, we can obtain the returns of the biggest portfolio in April and December. Finally, the 'March/April/December strategy' is a trading rule that we first buy the biggest portfolio at the end of February and sell it at the end of April, and buy the portfolio again at the end of November and sell it at the end of December. Using this strategy, we can obtain the returns of the biggest portfolio in Japan in March, April, and December.

Table 6 displays the profits obtained using the abovementioned strategies. Panel A provides the raw returns of the four strategies, and Panel B details their excess return over the market return. For market return, we employ the value-
'April strategy' earns an average annual excess return of 16.771 percent for the full-sample period, 20.692 percent for the earlier subsample period, and 12.850 percent for the later subsample period. Second, all four strategies using the April effect earn positive profits in all three sample periods. In particular, Panel B of Table 6 demonstrates that the 'March/April strategy' produces an average annual excess return of 18.570 percent for the full-sample period. As far as can be judged, this is the best strategy using the April effect for the biggest portfolio in Japan. In addition, the 'March/April strategy' earns an average annual excess return

\footnotetext{
${ }^{9}$ For example, see Billingsley and Chance [36. p. 28].
} 
of 21.873 percent for the later subsample period, even after taking transaction costs into account. We also note that as March and April are successive months, the 'March/April strategy' has smaller transaction costs because of the smaller number of transactions involved.

\section{Lowest-BE/ME Portfolio}

We now move on to the case of the April effect in the lowest-BE/ME portfolio in Japan. As shown in Fig. (2), the lowest-BE/ME portfolio in Japan earns higher returns in January, March, April, October, and November. Hence, we implement 11 strategies, which we refer to as the 'April strategy', the 'January/April strategy', the 'March/April strategy', the 'April/October strategy', the 'April/November strategy', the 'January/March/April strategy', the 'January/
April/October strategy', the 'January/April/November strategy', the 'March/April/October strategy', the 'March/April/ November strategy', and the 'April/October/November strategy'.

The transaction rule for each strategy is the same as discussed earlier, and again, we employ a cost of $0.85 \%$ for a round-trip transaction following Stoll and Whaley [35] and Billingsley and Chance [36]. We prove the profit results in Table 7. Once again, Panel A provides the raw returns of the strategies, and Panel B shows the excess returns over the market return. For market return, we again employ the valueweighted average return of all stocks listed on the TSE First Section (from the JSRI). The sample periods in Table $\mathbf{7}$ are the same as in Table $\mathbf{6}$.

Table 7. Profits for the Lowest-BE/ME Portfolio from Investment Strategies Using the April Effect: The Case of Japan from January 1982 to December 2007

\begin{tabular}{|c|c|c|c|c|c|c|c|c|c|}
\hline \multicolumn{10}{|c|}{ Panel A Raw Return } \\
\hline \multirow[b]{2}{*}{ Strategies } & \multicolumn{3}{|c|}{$\begin{array}{c}\text { Full-Sample Period: } \\
\text { January 1982-December } 2007\end{array}$} & \multicolumn{3}{|c|}{$\begin{array}{c}\text { Subsample Period: } \\
\text { January 1982-December } 1994\end{array}$} & \multicolumn{3}{|c|}{$\begin{array}{c}\text { Subsample Period: } \\
\text { January 1995-December } 2007\end{array}$} \\
\hline & $\begin{array}{l}\text { Transaction } \\
\text { Times }\end{array}$ & $\begin{array}{l}\text { Average } \\
\text { Yearly } \\
\text { Return }\end{array}$ & $\begin{array}{l}\text { Gross } \\
\text { Return }\end{array}$ & $\begin{array}{l}\text { Transaction } \\
\text { Times }\end{array}$ & $\begin{array}{l}\text { Average } \\
\text { Yearly } \\
\text { Return }\end{array}$ & $\begin{array}{l}\text { Gross } \\
\text { Return }\end{array}$ & $\begin{array}{l}\text { Transaction } \\
\text { Times }\end{array}$ & $\begin{array}{c}\text { Average } \\
\text { Yearly } \\
\text { Return }\end{array}$ & $\begin{array}{l}\text { Gross } \\
\text { Return }\end{array}$ \\
\hline April & 26 & 18.245 & 474.379 & 13 & 25.185 & 327.411 & 13 & 11.305 & 146.968 \\
\hline January/April & 52 & 19.316 & 502.217 & 26 & 34.159 & 444.072 & 26 & 4.473 & 58.145 \\
\hline March/April & 26 & 19.668 & 511.372 & 13 & 15.096 & 196.249 & 13 & 24.240 & 315.123 \\
\hline April/October & 52 & 18.896 & 491.283 & 26 & 25.440 & 330.724 & 26 & 12.351 & 160.559 \\
\hline April/November & 52 & 18.044 & 469.134 & 26 & 0.998 & 12.978 & 26 & 35.089 & 456.156 \\
\hline January/March/April & 52 & 19.624 & 510.233 & 26 & 24.158 & 314.060 & 26 & 15.090 & 196.173 \\
\hline January/April/October & 78 & 18.826 & 489.474 & 39 & 30.771 & 400.027 & 39 & 6.881 & 89.447 \\
\hline January/April/November & 78 & 18.258 & 474.708 & 39 & 14.477 & 188.197 & 39 & 22.039 & 286.511 \\
\hline March/April/October & 52 & 19.344 & 502.944 & 26 & 18.346 & 238.495 & 26 & 20.342 & 264.449 \\
\hline March/April/ November & 52 & 18.776 & 488.177 & 26 & 2.051 & 26.664 & 26 & 35.501 & 461.513 \\
\hline April/October/November & 52 & 18.828 & 489.518 & 26 & 9.514 & 123.681 & 26 & 28.141 & 365.837 \\
\hline \multicolumn{10}{|c|}{ Panel B Excess Return } \\
\hline & \multicolumn{3}{|c|}{$\begin{array}{c}\text { Full-Sample Period: } \\
\text { January 1982-December } 2007\end{array}$} & \multicolumn{3}{|c|}{$\begin{array}{c}\text { Subsample Period: } \\
\text { January 1982-December } 1994\end{array}$} & \multicolumn{3}{|c|}{$\begin{array}{c}\text { Subsample Period: } \\
\text { January 1995-December } 2007\end{array}$} \\
\hline Strategies & $\begin{array}{c}\text { Average } \\
\text { Yearly } \\
\text { Market } \\
\text { Return }\end{array}$ & $\begin{array}{l}\text { Average } \\
\text { Yearly } \\
\text { Excess } \\
\text { Return }\end{array}$ & $\begin{array}{l}\text { Gross } \\
\text { Excess } \\
\text { Return }\end{array}$ & $\begin{array}{c}\text { Average } \\
\text { Yearly } \\
\text { Market } \\
\text { Return }\end{array}$ & $\begin{array}{c}\text { Average } \\
\text { Yearly } \\
\text { Excess } \\
\text { Return }\end{array}$ & $\begin{array}{l}\text { Gross } \\
\text { Excess } \\
\text { Return }\end{array}$ & $\begin{array}{c}\text { Average } \\
\text { Yearly } \\
\text { Market } \\
\text { Return }\end{array}$ & $\begin{array}{l}\text { Average } \\
\text { Yearly } \\
\text { Excess } \\
\text { Return }\end{array}$ & $\begin{array}{l}\text { Gross } \\
\text { Excess } \\
\text { Return }\end{array}$ \\
\hline April & 9.577 & 8.668 & 225.379 & 13.369 & 11.816 & 153.611 & 5.785 & 5.521 & 71.768 \\
\hline January/April & 9.577 & 9.739 & 253.217 & 13.369 & 20.790 & 270.272 & 5.785 & -1.312 & -17.055 \\
\hline March/April & 9.577 & 10.091 & 262.372 & 13.369 & 1.727 & 22.449 & 5.785 & 18.456 & 239.923 \\
\hline April/October & 9.577 & 9.319 & 242.283 & 13.369 & 12.071 & 156.924 & 5.785 & 6.566 & 85.359 \\
\hline April/November & 9.577 & 8.467 & 220.134 & 13.369 & -12.371 & -160.822 & 5.785 & 29.304 & 380.956 \\
\hline January/March/April & 9.577 & 10.047 & 261.233 & 13.369 & 10.789 & 140.260 & 5.785 & 9.306 & 120.973 \\
\hline January/April/October & 9.577 & 9.249 & 240.474 & 13.369 & 17.402 & 226.227 & 5.785 & 1.096 & 14.247 \\
\hline January/April/November & 9.577 & 8.681 & 225.708 & 13.369 & 1.107 & 14.397 & 5.785 & 16.255 & 211.311 \\
\hline March/April/October & 9.577 & 9.767 & 253.944 & 13.369 & 4.977 & 64.695 & 5.785 & 14.558 & 189.249 \\
\hline March/April/ November & 9.577 & 9.199 & 239.177 & 13.369 & -11.318 & -147.136 & 5.785 & 29.716 & 386.313 \\
\hline April/October/November & 9.577 & 9.251 & 240.518 & 13.369 & -3.855 & -50.119 & 5.785 & 22.357 & 290.637 \\
\hline
\end{tabular}

Notes: 'Transaction times' is the number of transactions of each strategy in each sample period. 'Average yearly return' is the annual percentage return from each strategy over each sample period. 'Gross return' is the gross percentage return from each strategy for each sample period. 'Average yearly market return' is the annual percentage return of the weighted average return of the TSE First Section listed stocks in each sample period. 'Average yearly excess return' is the annual percentage excess return from each strategy over each sample period. 'Gross excess return' is the gross percentage excess return over the weighted average return of TSE First Section listed stocks from each strategy for each sample period. 
Table 7 provides the profitability of the lowest-BE/ME portfolio in Japan using our strategies. First, in terms of both raw and excess returns, the 'April strategy' produces positive profits in all three sample periods (Panel A). Second, Panels $\mathrm{A}$ and $\mathrm{B}$ show that all 10 combined strategies provide positive profits in the full-sample period. Focusing on the later subsample period, all 10 combined strategies except for the 'January/April strategy' also yield positive excess returns (Panel B of Table 7). Of all 11 strategies, in our full-sample period, the best performer is the 'March/April strategy', as for the biggest portfolio analyzed earlier. This has an average annual excess return of 10.091 percent. In the later subsample period, the best performer is the 'March/April/November strategy', earning an average annual excess return of 29.716 percent. As above, by combining the April effect with other seasonal monthly anomalies in Japan, we can consistently obtain positive profits over market return. We also note that not only the 'April strategy' but also any strategy including the 'March/April strategy' is a profitable strategy in Japan.

\section{CONCLUSIONS}

This paper examined the April effect in big and lowBE/ME firms in Japan for the first time. We computed wellknown Sharpe ratios and statistically evidenced the April effect in Japan. More concretely, our contributions in this paper are as follows.

- $\quad$ First, we provide new evidence that the biggest portfolio of 25 size-ranked portfolios in Japan earns the highest risk-adjusted returns in April. The existing studies of the January effect often connect this with a small-size effect. Thus our evidence and approach are quite different from that found in the existing literature.

- $\quad$ Second, we find that the lowest-BE/ME-ranked portfolio of $25 \mathrm{BE} / \mathrm{ME}-$ ranked portfolios also exhibits relatively higher risk-adjusted returns in April in Japan. This is also a new finding, because BE/ME portfolios were not generally analyzed from the perspective of seasonal anomalies.

- $\quad$ Third, we find that in both kinds of portfolios, volatilities are the lowest in April. This phenomenon is obtained from the viewpoint of time-varying volatilities.

- $\quad$ Fourth, we suggest that the Japanese April effect is not because of the well-known tax-loss selling effect but rather the combined influence of a turn-of-theyear effect and a dressing-up effect. This is because the larger transactions of Japanese financial institutions are made around the end of the Japanese fiscal year.

- $\quad$ Fifth, we also find that almost any trading strategy using this April effect can beat the market. This evidence is then highly suggestive in a business context as we demonstrate that profits can be obtained by using these trading strategies even after considering transaction costs.

As our evidence implies, because investor behavior is different in every country, the characteristics of stock markets should be independently and carefully researched using data in each country.

\section{ACKNOWLEDGEMENTS}

The author acknowledges the generous financial assistance of the Japan Society for the Promotion of Science and the Zengin Foundation for Studies on Economics and Finance. The author is also grateful to two anonymous referees for their constructive comments on an earlier version of the paper, and to Matthew Honan and Ambreen Lodhi for the invitation to write to this journal.

\section{REFERENCES}

[1] Rozeff MS, Kinney WR Jr. Capital market seasonality: The case of stock returns. J Financ Econ 1976; 3: 379-402.

[2] Keim DB. Size-related anomalies and stock return seasonality: Further empirical evidence. J Financ Econ 1983; 12: 13-32.

[3] Reinganum MR. The anomalous stock market behavior of small firms in January. J Financ Econ 1983; 12: 89-104.

[4] Branch B. A tax loss trading rule. J Bus 1977; 50: 198-207.

[5] Roll R. The turn-of-the-year effect and the return premia of small firms. Working Paper, Graduate School of Management: University of California 1982.

[6] Roll R. Vas ist das? The turn-of-the-year effect and the return premia of small firms. J Port Manage 1983; 9: 18-28.

[7] Blume ME, Stambaugh RF. Bias in computed returns: An application to the size effect. J Financ Econ 1983; 12: 387-404.

[8] Brauer GA, Chang EC. Return seasonality in stocks and their underlying assets: tax-loss selling versus information explanations. Rev Financ Stud 1990; 3: 255-80.

[9] Sias RW, Starks LT. Institutions and individuals at the turn-of-theyear. J Finance 1997; 52: 1543-62.

[10] Grundy BD, Martin JS. Understanding the nature of the risks and the source of the rewards to momentum investing. Rev Financ Stud 2001; 14: 29-78.

[11] Poterba JM, Weisbenner SJ. Capital gains tax rules, tax-loss trading, and turn-of-the-year returns. J Finance 2001; 56: 353-68.

[12] Ali A, Hwang LS, Trombley MA. Arbitrage risk and the book-tomarket anomaly. J Financ Econ 2003; 69: 355-73.

[13] Vorkink K. Return distributions and improved tests of asset pricing models. Rev Financ Stud 2003; 16: 845-74.

[14] Grinblatt M, Keloharju M. Tax-loss trading and wash sales. J Financ Econ 2004; 71: 51-76.

[15] Grinblatt M, Moskowitz TJ. Predicting stock price movements from past returns: the role of consistency and tax-loss selling. J Financ Econ 2004; 71: 541-79.

[16] Ng L, Wang Q. Institutional trading and the turn-of-the-year effect. J Financ Econ 2004; 74: 343-66.

[17] Starks LT, Yong L, Zheng L. Tax-Loss selling and the January effect: Evidence from municipal bond closed-end funds. J Finance 2006; 61: 3049-67.

[18] Cooper MJ, McConnell JJ, Ovtchinnikov AV. The other January effect. J Financ Econ 2006; 82: 315-41.

[19] Banz RW. The relationship between return and the market value of common stocks. J Financ Econ 1981; 9: 3-18.

[20] Reinganum MR. Misspecification of capital asset pricing: Empirical anomalies based on earnings yields and market values. J Financ Econ 1981; 9: 19-46.

[21] Reinganum MR. A direct test of Roll's conjecture on the firm size effect. J Finance 1982; 37: 27-35.

[22] Roll R, A possible explanation of the small firm effect. J Finance 1981; 36: 879-88.

[23] James C, Edmister RO. The relationship among common stock returns, trading activity and market value. Working Paper, Graduate School of Business: University of Oregon 1981.

[24] Brown P, Kleidon A, Marsh T. New evidence on the nature of sizerelated anomalies in stock prices. J Financ Econ 1983; 12: 33-56.

[25] Stoll HR, Whaley RE. Transaction costs and the small firm effect. J Financ Econ 1983; 12: 57-79.

[26] Fama E, French K. The cross-section of expected stock returns. J Finance 1992; 47: 427-65.

[27] Jegadeesh N, Titman S. Returns to buying winners and selling losers: Implications for stock market efficiency. J Finance 1993; 48: 65-91.

[28] Rouwenhorst KG. International momentum strategies. J Finance 1998; 53: 267-84. 
[29] Jegadeesh N, Titman S. Overreaction, delayed reaction, and contrarian profits. Rev Financ Stud 1995; 8: 973-93.

[30] DeBondt WFM, Thaler R. Does the stock market overreact? J Finance 1985; 40: 793-805.

[31] Kato K, Schallheim JS. Seasonal and size anomalies in the Japanese stock market. J Financ Quant Anal 1985; 20: 243-60.

[32] Gultekin MN, Gultekin NB. Stock market seasonality: International evidence. J Financ Econ 1983; 12: 469-81.
[33] Fama E, French K. Common risk factors in the returns on stocks and bonds. J Financ Econ 1993; 33: 3-56.

[34] Hamao Y. An empirical examination of the arbitrage pricing theory. Japan World Econ 1988; 1: 45-61.

[35] Stoll H, Whaley R. Expiration day effects of index options and futures. Working Paper, Vanderbilt University 1986.

[36] Billingsley RS, Chance DM. Put-call ratios and market timing effectiveness. Financ Anal J 1988; 15: 25-8.

(C) Chikashi Tsuji; Licensee Bentham Open.

This is an open access article licensed under the terms of the Creative Commons Attribution Non-Commercial License (http://creativecommons.org/licenses/by$\mathrm{nc} / 3.0 /$ ) which permits unrestricted, non-commercial use, distribution and reproduction in any medium, provided the work is properly cited. 